|IIIIIIIIIIIIIIIIIII

特別記事

IIIIIIIIIIIIIIIIIIIII

\title{
IUPAC 2019 Ghent Crop Protection Chemistry ${ }^{\#}$
}

\author{
横井大洋, 甲斐建次, 岡澤敦司, 橋床泰之, 中川好秋
}

(2019年12月 18 日受理)

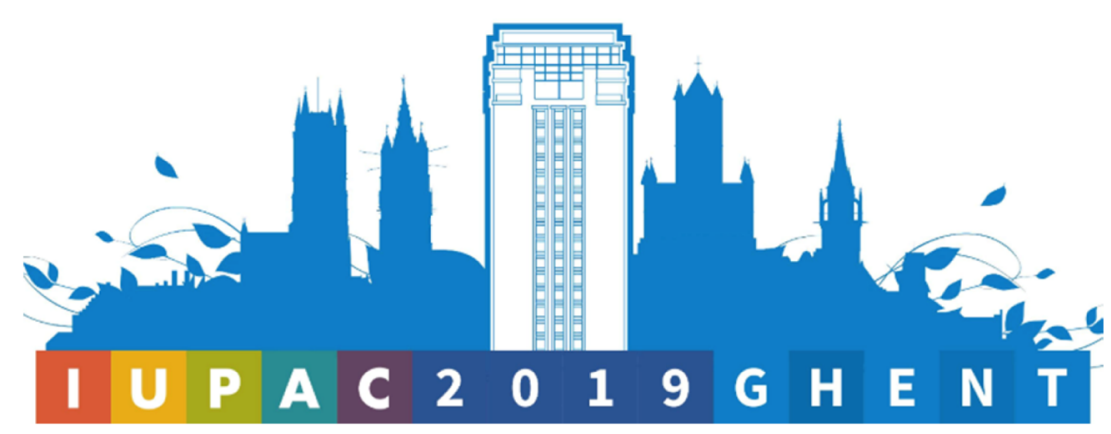

\section{1. はじめに}

本国際会議が，ベルギーヘント市（図1）の International Convention Center Ghent（ICC：図2）において, 2019年 の5月19日から24日の6日間にわたって開催された. 前回 は2014年にサンフランシスコにおいて第13回 ICPC（International Congress of Pesticide Chemistry) として開催され た. 2014 年には『次回は2018年にリオデジャネイロ開催 予定』というアナウンスがなされていたが, ベルギーに変 更された．急な変更で 1 年間延期され2019年の開催となっ た.今回はPesticide ChemistryではなくCrop Protection Chemistryという名称が使われていた. 本会議終了後の5/31 にIUPAC2019事務局から届いたメールによると, 参加者は 1,572名であった. そのメールには, 学会中に撮影された写 真のダウンロードサイトが示され, 特別講演も YouTubeで 拝聴できるようになっていた，学会もインターネット時代に 入ったことを実感した。

これまでの学会誌におけるIUPAC報告としては, 第 12 回 ICPC (メルボルン) に関して 61 ページ（第36巻 1 号, pp. 141-201), 第 13 回 ICPCは35ページ（第 40 巻 1 号, pp. 105-139）掲載されている. 第13回ICPCに関しては, 渡航援助を受けた 9 名の学生からの報告書が電子版で公開

\# IUPAC 2019 (Yoshiaki Nakagawa)

(c) 日本農薬学会
されている. 今回も, 特にICPC特集をすることは計画しな かったが, 本会議に出席するために農薬学会から渡航補助を 受けた横井, 甲斐, 岡澤, 橋床と編集委員長の中川が手分け して会議の報告をさせていただくことにした. 現在Journal of Pesticide Science（JPS）の審査部門を, 除草, 殺虫, 殺 菌, 環境に分けていることから, その分類に分けて報告さ せていただく、環境・製㓮部門をお願いした橋床氏（北海 道大）におかれては, 10 月初めに緊急入院され, 残念なこ とに本報告書提出（11月3日）直後の 11 月 22 日に他界され た. 報告書の送付のメールの追伸に『こういう作業をやって

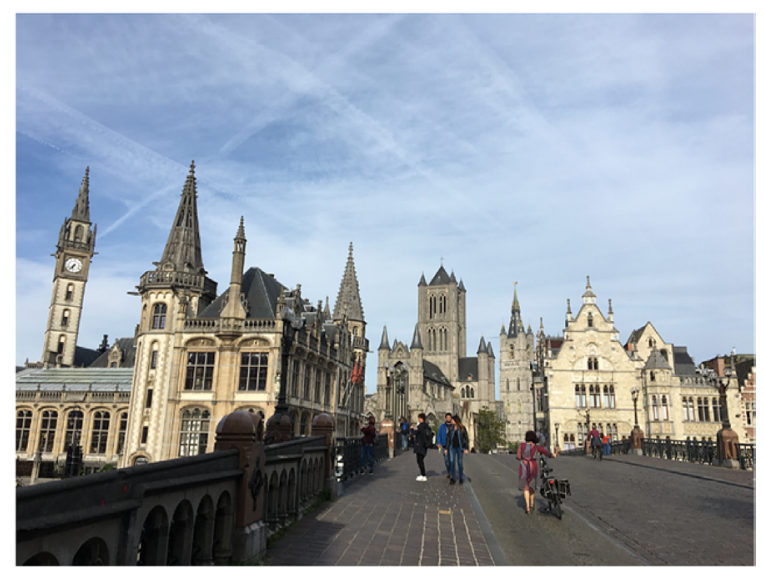

図1. ヘント市の風景. 


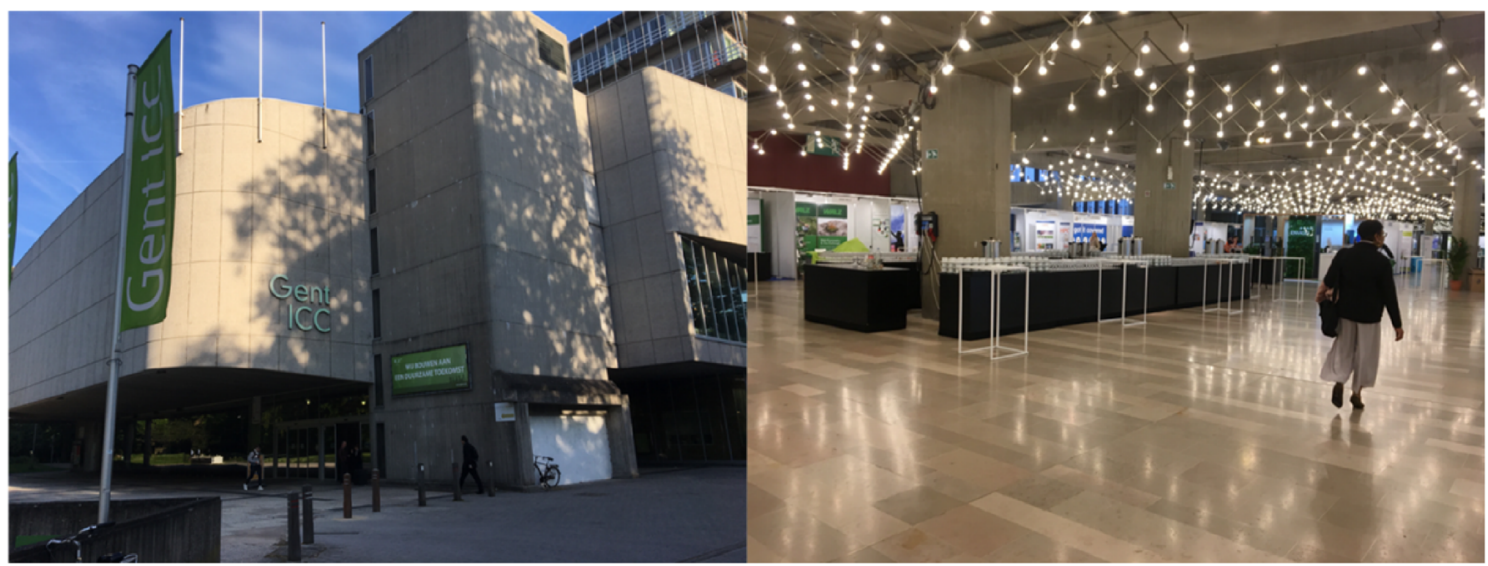

図2. 会場の外観と会場内の様子.

いる方が，どうも体調が良いようです.』と書かれていたの を痛々しく思っていたが，その直後に亡くなられ，これが絶 筆となってしまった。橋床先生のご冥福をお祈りしたい。

\section{2. オープニングセレモニー}

19日は15:00から Registration, 16:30から Opening Session, 18:00から Welcome Receptionが行われた。筆者（中川）は オープニングセレモニーには参加していないので，その紹介 をすることはできないはずだったが，学会終了後にオープン ニングレクチャーをYouTubeで聴くことができたので，そ れを紹介する。最初は実行委員のPieter Spanoghe氏とNathan De Geyter氏によって，本国際会議を引き受けることに なった経緯などが話された。本会議のテーマはSustainabilityと Next generationであるということであった. Spanoghe 氏の講演では，自分の父が小さい頃に雪遊びを楽しんでいる 様子を動画で示され，ビル・ゲイツ氏を特別講演に招待しょ うという計画があったことも述べられた。

次はIUPACの第6部会 (Division of Chemistry and the Environment）の中の Advisory Committee on Crop Protection Chemistryを代表して Laura McConnelがIUPACの紹介を 行った. 続いて, Ken RackeがCrop Protection Chemistry の会議の歴史を紹介した（表1）。この会議は，1967年に オーストリアで第 1 回が開催され，基本的に 4 年に 1 度開催 されてきた。日本ではこれまでに 2 度開催された。1982年 に京都で第5回が，2006年には神戸で第10回が開催された。 Rackeは1986年のオタワで初めて参加したとのことであっ た、筆者（中川）は，1982年の博士課程のときに京都でポ スター発表を行ったのを今でも鮮明に覚えている．続いて， Advances in Harmonized Approaches to Crop Protection Chemistry という IUPAC の国際賞がMark R. Lynch に決定し たことが発表された。残念なことに，Lynchは2018年に他 界したため, 賞状などが家族に授与され, 受賞講演は代わり に Gordon Rennickが行った.
20日から Scientific Programがはじまり，24日の午前中ま で（ポスター発表は23日まで）行われた。毎日, 8時半から 基調講演, 夕方にはディベートが行われたが, これらはすべ てFemi Oke女史によって切り盛りされた，それぞれの基調 講演が終わると, 講演者とOkeがソファーに座ってインタ ビューが行われ, 会場からの質問が受け付けられた. 基調講 演という堅苦しさはなく，なごやかな感じで進行されていた のが印象的だった．質問では，マイクロホンが青と赤のスポ ンジのキューブに取り付けられていて, 係員がマイクを持っ て走り回るのではなく, 投げ渡すという面白い試みがあっ た. 今回の会議はコミュニケーションを第一に考えていた ように思う。一日の打抢々のスケジュールは, 午前 8 時に ポスター展示, 8:30-9:45 まで基調講演, コーヒーブレーク, オーラルセッション, 昼食をはさんで, 午後は 13:00からポ スター発表, オーラルセッション, コーヒーブレーク, そし

表1. IUPAC農薬化学会議の歴史

\begin{tabular}{rrll}
\hline 回 & 開催年 & \multicolumn{1}{c}{ 国 } & \multicolumn{1}{c}{ 市 } \\
\hline 1 & 1967 & オーストリア & ウイーン \\
2 & 1971 & イスラエル & テルアビブ \\
3 & 1974 & フィンランド & ヘルシンキ \\
4 & 1978 & スイス & チューリッヒ \\
5 & 1982 & 日本 & 京都 \\
6 & 1986 & カナダ & オタワ \\
7 & 1990 & ドイッ & ハンブルグ \\
8 & 1994 & アメリカ合衆国 & ワシントンD.C. \\
9 & 1998 & イギリス & ロンドン \\
10 & 2002 & スイス & バーゼル \\
11 & 2006 & 日本 & 神戸 \\
12 & 2010 & オーストラリア & メルボルン \\
13 & 2014 & アメリカ合衆国 & サンフランシスコ \\
14 & 2019 & ベルギー & ゲント \\
\hline
\end{tabular}


て1時間のディベートと続いた．22日は午後に，エクスカー ションが行われ, 農場の見学, 古い町並みなどのツアーが あったようだが，帰宅は 23 時とか 24 時とかになったと聞い ている. 23日は19時頃から Banquetが開催された。最初は, 立ちながらビールやシャンパンと軽い食事を頂いた。1時間 程度経過したのち，好きなところに着席して，メインの食事 （魚，チキン，デザート）を楽しんだ。終了時間は23時で あったが，それまでに徐々に席を離れて帰宅した参加者もい た.メインの食事の間に, 楽器をもった数人が各テーブルを 回って演奏し, 歌ってくれたのは楽しかった.

\section{3. 基調講演}

1 日目の基調講演は，2016年にノーベル化学賞を受賞し たFraser Stoddart（Northwestern University, USA）が行っ た.ノーベル化学賞の受賞タイトルは「分子マシンの設計と 合成」で，フランスの Jean-Pierre Sauvage とオランダのBen Feringa との共同受賞であった. Stoddartは, 1978-1981 年にかけてICIで共同研究を行い，除草剂のParaquatや Diquatの研究にも関わったようである. Revolutionaryと Evolutionaryの違い, Applied と Basicの違いを述べられた. 研究においても学生の教育が大切で, 研究のオーナシップは 学生に取らせているということであった, すなわち, 学生を 手厚くしっかりとサポートして口頭発表や論文執筆では学生 をトップに据えるということであった。 また，印象に残った のは, 講演で分子を動かしながら, その間に女性と社交ダン スされたことで, 日本の学会ではなかなか見られないことで あった。

2日目は, Biopesticideに関するもので, Monica Höfte (Ghent University, Belgium) は「Cyclic lipopeptides (CLiP): versatile molecules for plant disease control」という講演を 行った. CLiPsの構造は脂肪酸部と環状ペプチドで構成さ れ, BacillusのCLiPsは，3つのグループに分けられてい る.すなわち, Surfactin（C12-C17脂肪酸，7個のアミノ酸 が環状), Iturin（C13-C20脂肪酸，7個のアミノ酸が環）, Fengycin（C13-C19, 10個のアミノ酸で 8つのアミノ酸が環 状）で，CLiP を生産するBacillusは生物農薬として市販され ているが，ここでは, Pseudomonas生産CLiPsについて紹介 された. Pseudomonas属は Gram-negativeで, 土堙. 水系, 植物, 動物で見いだされ, 人や植物の病気, biocontrol, 植 物生長の刺激, bioremediationに関与し, 現在 100 種以上が 存在する。Pseudomonas属では2次代謝物も多様である。実 際にイネにおいて, Pseudomonas CLiPsで誘導されたいも ち病抵抗性が示された。

2つ目の講演は, Pam Marrone（Marrone Bio Innovation, USA）による「History, status and potential of natural products for pest management and plant health」であった. 講 演者の父が農業を行っていたが，Gypsy mothによって被害
を受け，それがBT剤の散布によって防除できたことに感動 し, 講演者の将来の研究へ導くことになったとのことであ る. 生物農薬が化学農薬に比べて有用であることが述べら れた。すなわち, 生物農薬は総合防除プログラム（IPM）に のっとっていて, 製品の品質もよく科学的な検証も行われて いる．製剤化および製造技術も進歩していて，ユニークな株 /種が見つかっている，収穫までの残留物の管理も容易であ る. 作用性が複雑であるが, 従来の化学薬品に対する耐性発 現が遅れるメリットがある。作業者にとっては安全で環境破 壊のリスクは低く, 土壌に対す悪影響もなく, 花粉媒介虫に 対する安全性も高い, 何より, 開発コストが低いというメ リットがある。

3日目の最初は, Nuri Gras (Chilean Food Safety and Quality Agency, Chile) による「Emerging food safety issues/risks: New challenges for Latin American countries $\lrcorner と$ いう講演であった, Foodbone disease（FBD）の問題が提 起された. WHOによると，2010年には，6億人（世界人 口の 1/10）がFBDにさらされ，それが原因で 42 万人が死 に至り，その $1 / 3$ が 5 歳以下の子供であるとのことであっ た. 気候変動と FBDによって様々な問題が引き起こされて いることが強調されていた．例えば洪水によって化学物質 が流出して環境が破壊され, 気候変動は穀物だけでなく海 産物にも影響を与えているということである.このような 中で, チリではACHIPIAという協会を作って食の安全と 質を保証するようにしているとのことである，今後も政府， 学協会, 社会, 個人でコミュニケーションをしっかり取っ て, 気候変動やFBDによって引き起こされる課題に対し協 力していくことが必要であるということで, 締めくくられ た. 2つめはJacob van den Borne (van don Borne Aardappelen, Netherland）で「Precision agriculture in practice」と いう講演で, AIやロボットを使った農業ビジネスが紹介さ れた。「精密農業」とは, 正しい時期（time）に正しい場所 (location) で正しい技術（application）を使って農業を行う ことである。ただ，この「精密農業」の誕生はいつ頃かと聞 かれると，それは実はずっと前から実施しているということ であった. 自分の祖父が70年前にすでにそれをやっていた とのことである.すなわち, 毎日の農作業の詳細を手帳記録 し，データを解析して次に役立てていた，正にこれが精密農 業で, 今は, 手帳がコンピューターに変わったということ と, 大型機械, ドローンといった新しい技術が使えるという ことである. 最新の機械を使って, 必要な場所に, 必要なだ けの農薬の散布が可能である.

4 日目の最初はHlami Ngwenya (University of Free State, South Africa) で, 「PERFECT opportunities for REALsearch in AgriCOOLture」という講演であった. 作物についてでも なく, 農業についてのものでなく, 教育に関するものであっ た. 講演の冒頭で, 若い人のほとんどは農業には興味がな 
く，それは農業をやっていてもお金持ちにはなれないこと が原因であると述べられた。このことは, 筆者が子供の頃 から専業農業者であった親から言われてきたことで，今の 日本でも大半の農業従事者に当てはまることであろう．演 題のタイトルのはじまりがPERFECT opportunitiesで，そ のPERFECTの意味が説明された。すなわち, PERFECT $と は$, Policies, Education and training, Research, Farming, Finance, Extension \& Advisory Services, Communications, Technologies, Tradeの頭文字で構成されているということ であった. Educationは大学だけでなく初等教育, 職業訓練 においても重要である。ここでの Research は作物科学であ るが, そこには気象学, 経済学, 生化学, 社会科学, 食品化 学. 統計学など, 様々な学問領域が関連しているとのこと であった．講演の最後に“Perfect opportunityisnowhereはど う読むか”という質問が会場に投げかけられた。すなわち，“

Perfect opportunity is nowhere" $と も "$ "Perfect opportunity is now here”とも読め, どちらも正解であるということであっ た. 最後は, For PERFECT opportunities for REALsearch in AgriCOOLture という箱の外を見ましょうという締めくく りであった.2つ目は, Vytenis Andriukaitis（EU Commissioner on Food \& Health-European Commission Lithuania) による「The EU's plant protection policy: Lessons learned and next steps」という講演であった. 前の演者が AgriCOOLture と, COOLを強調していたが，自分の講演は, CoolではなくHotで, 非常にやりにくい講演ですという切 り出しで始まった。サイエンスではなく，政治的なものであ ることが強調されていた。過去 5 年に打けるEUに扔けるパ ブリックコメントとして，『農薬は悪で危険なものであるが， それは偏見によるもので，コミュニケーションのないもので ある』とされた。例として, リンゴの話があった。リンゴは ビタミンなど豊富で健康によい食品であるが, リンゴを食べ ている子供に，「なぜリンゴは身体にいいの」と聞くと，「マ マがオーガニックと言っていたから」という返事であった。 農薬に対してほとんどの論文が否定的でほんの一部が肯定的 という偏った情報提供はいかがなものか，タバコを吸って多 くの人が亡くなっているのに対し, 遺伝子組み換え作物を 食べて何人亡くなったか? もちろん，農薬などの使用を間 違うと問題は起こるが，そ机はあくまでも個人的な問題であ る.とにかくコミュニケーションは非常に重要で, 声を出さ なければ，何でも“禁止”，“禁止”となって，社会（ユニオ ン）はこわれてしまうと危ぶんでいた，

最終日（5日目）は，帰りのフライトの都合で，参加する ことはできなかったが, YouTubeで講演を拝聴した。一人 目は, 中国のXuhon Qian (East China Normal University, China) で, 「Research and development of green pesticides in China」という講演であった. Qianは筆者の友人で, 彼 のことをよく存じ上げているが，スライドでは筆者の恩師で
ある（故）藤田稔夫名誉教授が紹介されていた，講演の中心 は, 中国における農薬研究開発で, アカデミアで活躍中の研 究者の写真と化合物の構造式を紹介しながらその成果が紹介 された，基礎研究から実用までの幅広い研究が紹介された。 すなわち、コンピューターを使った新剂の探索と構造の最適 化, 天然物からの構造展開などが紹介された. Qianの研究 成果のなかで，主たるものはNeonicotinoids研究で，80報 の学術論文が報告され，55の特許，39の国際特許出願され， 2つの化合物 aichongding と cycloxapridが実用化に至ったと のことであった. 会場から, 中国の農薬に関する問題（ジェ ネリックや毒性）に関して厳しい質問が投げかけられた。そ れに対して, 『中国は 20 年程前まではかなり問題が多かっ たが, 今ではかなり改善され, greenに傾いている』という 返答が行われた，最後の講演はDavid Zaruk（Odisee University College, Belgium）によるもので, 講演タイトルは 「Block chain trust」であった。 タイトルを見てもよくわから ず，何度もYouTubeで講演を聴き直したが，結局はよくわ からなかった，英語は比較的聞き取りやすかったが，一体何 を言いたいのかがわからなかった，Block chainをGoogleで 調べて見ると, 分散型ネットワークで, 代表的なものとして ビットコインがあると書いてあった，話の中で，演者がバッ グから傘を出してたとえ話をしていたが, 研究成果とその評 価との関連について言いたかったのではないかと思った。す なわち, 天気のいい日になぜ傘を持ってきたか，それを間違 いとするか，あるいは翌日あるいは翌々日に雨になるかもし れないので正解となるのかもしれない，何が正しくて，何が 間違いかはわからないという結論だったのであろう。

本会議は 10 のトピックに分類され，トピック 2 は共同開 催していたISCP (71st International symposium on crop protection）のものであった. 会議のトピックは以下のとお りであった。

Topic 1: Emerging issues and challenges

Topic 2: ISCP-Novel agricultural technology ISCP 71st International symposium on crop protection

Topic 3: Discovery and optimization of crop protection products

Topic 4: Formulation and application technology

Topic 5: Non-dietary human health hazard, exposure and risk

Topic 6: Food quality and safety

Topic 7: Environmental fate, transport and metabolism

Topic 8: Ecosystem and ecological risk assessment

Topic 9: Mode of action and resistance

Topic 10: Stewardship, regulation and communication 


\section{4. 招待講演}

1日目（月）の午前はTopic 1-3, 5, 7-9が, 午後はTopic 2-9が10会場で行われた。 2日目（火）の午前はTopic 1-7, 9で 10 会場, 午後はTopic 1-4, 6,7,9で8会場, 3日目（水） はTopic 1-4, 6, 7, 9のセッションが午前中に行われた. 午後 はエクスカーションのため, セッションは設けられなかっ た. 4 日目 (木) はTopic 1-4, 6, 7, 9で7会場, 午後はTopic 1-4, 6, 9で，7会場で行われた。最終日（金）は午前中のみ で, Topic 3, 6, 7 の講演が5会場で行われた. Topic 3（New Chemistry）に関しては，最終日に，優秀ポスターに対して ショートプレゼンテーションが行われたようである.

1日目（May 20）の Topic 3 (New Chemistry) はほかの トピックに比べて会場は広く，聴衆も多かったように思う。 新剂に関しては日本からの講演が多く, 日本の開発力の高さ が際立っていた，殺虫剤に関しては，日本から午前中 3 題, 午後に 1 題の発表が行われた. 三井化学からはBroflanilide, 日産化学からはFluxametamide, 石原産業からはCyclaniliprole, 日本農薬からはBenzpyrimoxanに関する発表が行わ れた。ほかのオーラルセッションのトピックとしては，持 続可能な水の利用や農業労働者のトレーニング（Topic 1), RNAを使った生物制御やナノテクノロジー（Topic 2), 食 品における残留分析の最先端技術 (Topic 3), デジタル農 業 (Topic 4), 散布者など作業員の動きと曝露の危険性 (Topic 5). 農薬の土壌, 水系, 大気, 作物における運命や 輸送 (Topic 7), 非標的生物に対する農薬の影響（Topic 8), 除草剤の作用機構と抵抗性（Topic 9）であった。ポスター セッションは, Topic 1, 5, 7,8で行われた.

2日目（May 21）の Topic 1では21世紀の農薬の管理とデ ジタル化や精密農業の効果を探る規制上の意思決定における 新しいパラダイム．微生物農薬のセッション（Topic 2）で は, 雑草, 害虫, 病気のモニタリング, 生物を使った防除, 昆虫の挙動に基づいた技術，リポペプチドを生産するベトナ ムの硫酸酸性土壌, イネ根圈から単離された環状リポペプチ ド生産菌の多様性と生物活性. カイコ由来の細胞 (Bm12) における抗菌ペプチド（Destruxin A）の結合タンパク，耐 雨性やUV抵抗性を増強した微生物農薬, 総合的線虫防除, 生物農薬にたいする持続可能な補助製剂の同定と評価. 新 しい生物農薬V Velifer（BASF），トマトハモグリバエに対する 現地昆虫病原性細菌の効果などが取り上げられた。Topic 3 は殺菌剤の New Chemistryであった。初日と同様に日本か らの講演が多く, 住友化学の Inpyrluxam, 石原産業の Isofetamid, 住友化学の Methyltetraproleが紹介された. 海外から は, Adepidyn (Syngenta), Isoflucypyram (Bayer), さび病 に高い効果を発揮するオキサジアゾール，Revysol（BASF）, florylpicoxamid (CORTEVA), Azole carbinol (FMC), ま た，新しいタイプの oxysterol binding protein inhibitor (Syngenta）や，殺菌剤の標的として pyruvate kinase（中国）の講
演が行われた. Topic 4 は製剤に関するもので, 濡れ, 液滴 固着に及ぼす葉の表面構造の影響, 葉の表面にインパクトを 与える水滴のイメージ解析, 殺虫剂の効力を最適にするスプ レーの特徵, 殺菌浏の効率におけるアジュバントとスプレー 量減量との関係, モデル表面における農薬液滴の乾燥 : 有効 成分とアジュバントの共局在性, 製剂開発における活性成 分と製品のマネージメントによる製品最適化, Fox Xpro と いう新しい製剂概念などが議論された。Topic 5 では毒性の メカニズム, 基準設定, 調和のとれたアプローチが紹介さ れた，食品に関するセッション（Topic 6）では食品の製造, トレード, 偽装, 信頼性, 新規な食品, 食品における農薬残 留分析のための近代的な技術についての討論が行われた。 食 物連鎖を通しての食の安全管理, レタス, キュウリ, ニラに おける低残留収穫, 有機産物認証のための野菜と土鐶との間 で安定同位元素比の利用 (スペインの農場), 分析用サンプ ルの調製と, GC-MS, GC-MS/MSを使った農薬の残留分析, 環境にやさしい作物保護剤の開発などの話題が提供された. Topic 7 は環境動態や毒性に関するセッションであったが, 日本からの講演はなく, 欧米からの発表が中心であった。農 薬混合物と他の污染物質との相互作用：環境運命プロセス, 曝露およびリスク評価, 農薬のバイオアベイラビリティと生 体内蓄積 : 農薬の環境運命におけるそれらの役割が議論され た. 農薬の散逸と代謝における非生物的プロセス（収着, 揮 発, 光分解, 加水分解) の寄与に関しても議論が行われた. Topic 9は作用機構と抵抗性に関するセッションで, 午前は 殺線虫剂に関するもので, たとえば, 植物寄生線虫における セロトニンシグナル, G. pallidaの代謝物の調査, 殺線虫性 Fluopyram の作用機構, 線虫のアセチルコリン受容体に関す る発表が行われた。午後はゲノム技術に関するもので, 新技 術を用いた作用機構診断, 高分解QTLマッピング, 定量的 化学アプローチ, 標的特異的な抵抗性発現, 植物抵抗性に基 づく新しい農薬の開発と作用機構などが議論された。

3日目（May 22）のTopic 1ではライフサイクル製品の管 理, 貿易の加速一グローバルな最大残留基準值（MRL）の 必要が議論され, Topic 2では生体刺激剂, Topic 3 は, 動物 の寄生虫, 線虫, ベクターを標的とする剤の New Chemistryに関する討論が行われた．Topic 4 はドリフトに関するも の, Topic 6 は食品や飼料における農薬残留の検出と制御の ための最新技術と殺虫剂の作用機構と抵抗性に関しての話題 提供であった. Topic 7では農薬の生分解と代謝と農薬の環 境曝露の数学モデルの進歩が紹介された. 午後はエクスカー ションであった。

4日目（May 23）のTopic 3 は除草剤の New Chemistry で，まずFMCからジヒドロオロト酸デヒドロゲナーゼ（キ ノン）を阻害する新しい作用機作の aryl pyrrolidinone anilidesが紹介された，続いてBASFから Luximo, そして日本 の三井化学アグロから cyclopyrimorate という新しい水田用 
除草剂の発見と作用機構が紹介された。それ以外では，生物 除草剂Spliceostatin C, 天然物除草剂 Isoxazolopyridines $の$ 講演があった。午後も引き続いて除草剤の New Chemistry に関する討論で，新しいHPPD阻害剤，Tirexor, Rinskor, $N$ phenylazole, uracil, 1-furan-2-yl)methylphosphonatesが紹 介された．Topic 1では，フェークニュースにおける科学通 信，リスク評価とハザードベースの意思決定などの討論が行 われた。 Topic 2では，天然物を使った防除について，USA から 4 題，あとは中国，心゙ルギー，オーストラリアから 1 題 ずつであった．午後も引き続いてTopic 2 のッションがあ り，RNAによる生物制御や天然物に関する議論がなされた。 革新的でグリーンな製剤技術などが紹介された（Topic 4). Topic 6では，食事のリスク評価と意志決定の進歩と消費者 保護のための最大残留基準値（MRL）と国際ガイドライン ／基準／規制について議論された。Topic 7では環境への農 薬放出の緩和と管理，そしてTopic 9では殺虫剤の作用機構 と抵抗性に関しての話題提供が行われた。

5日目は作物保護の新しいアプローチとして，日本の Meiji Seika Pharmaの大山氏とUSAの演者が天然物探索に ついて講演し，それ以外は中国，フランス，イスラエルか らの講演であった（Topic 3). ギリシャ，スウェーデン， USA, フランス, ベルギー, アルゼンチンからサンプリン グ法，分析およびモニタリングの進歩に関して（Topic 6, 7） の講演が行われた. Topic 3 と7に関しては, ポスターセッ ションの中から興味ある話題が選抜され，ショートプレゼン テーションが行われた。

上に示した会議のトピックと若干異なるが，ポスター発 表は下記の9つのトピックに分類された。申し込まれたポス ター発表は328件であった。いつものことではあるが，その うち 50 件近くのポスターは揭示されていなかった．国別で は発表の多い順に，中国（57件），USA（33件），UK，ベル ギー (29件), ドイツ（28件）で日本は第6位で23件であっ た.9つのポスタートピックの中で, Topic 3 (Discovery) への申し込みが最も多く90件あった. Topic 3 に扔いても， 中国からの申込みが 27 件で最も多く，約 $1 / 3$ を占めていた。 続いて，ドイツ（14件）と日本（13件）であった．欧米か らは，どちらかというとDiscoveryよりも環境製剤関係の発 表が多かった。また，ポスター発表に対しては，ポスター賞 が設けられていたが，日本からは，大阪府立大学の甲斐建次 氏（Topic 3）と近畿大学の松田一彦氏（Topic 9）が受賞さ れた。

Poster Topic 1: Stewardship, regulation and communication: future challenges (Topic 1, 10)

Poster Topic 2: ISCP-Novel agricultural technology (Topic 2)

Poster Topic 3: Discovery and optimization of crop protection products (Topic 3 )
Poster Topic 4: Formulation and application technologies (Topic 4)

Poster Topic 5: Non-dietary human health hazard, exposure and risk (Topic 5)

Poster Topic 6: Food quality and safety（Topic 6)

Poster Topic 7: Environmental fate, transport and metabolism (Topic 7)

Poster Topic 8: Ecosystem and ecological risk assessment (Topic 8)

Poster Topic 9: Mode of action and resistance (Topic 9)

以下に，渡航援助を受けた 4 名が，殺虫剤，除草剂，殺菌 剤，環境・製剤などに分けてまとめた。各演題のあとにプロ グラム番号をつけてあるので, 講演要旨（電子版）をお持ち の方は，それを参考にしていただきたい.

(中川好秋)

\section{5. 殺虫剤}

Discovery, synthesis and structure-activity relationship of tetraniliprole (VAYEGO ${ }^{\mathrm{TM}}$ ), a novel diamide insecticide Fischer et al. (Bayer AG) (3.1.4)

本講演では, Bayer社により開発された新規殺虫剂 tetraniliprole（図3）の開発までの経緯が紹介された. Tetraniliproleは昆虫筋肉細胞内のリアノジン受容体（RyR）を活性化 する diamide系殺虫剂であり, 昆虫に異常な筋収縮を引き 起こして殺虫効果を示す. Bayer社において, 既存剤である chlorantraniliproleをリードとして広範な構造展開が行われ た結果，ピラゾール環上の $\mathrm{Br}$ 基部分を変換した化合物におい てのみ殺虫活性の向上が認められ, 最終的に tetraniliproleが 選抜された。リード化合物と比較すると，ベンゼン環上の $\mathrm{Cl}$ 基が $\mathrm{CN}$ 基に置換されているが（cyantraniliprole と同様の構 造), この変換は土㙵中での安定性改善に寄与している. $\mathrm{Br}$ 基を置換テトラゾール環に変換するという大きな構造変化に もかかわらず，実用レベルの殺虫活性が保持されるという点 は非常に興味深い. Diamide系殺虫剂の RyR との相互作用を 理解するうえで，本剤は重要な手がかりになると感じた。

Cyclaniliprole: A novel diamide insecticide Tsukamoto, et al. (Ishihara Sangyo Kaisha, Ltd.) (3.1.5)

本講演も, 新規 diamide系殺虫剂の開発に関するものであ る. Chlorantraniliproleをリードとし，（1）ベンゼン環上メ チル基の $\mathrm{Br}$ 基への変換，(2）アミド窒素上メチル基の1-cyclopropylethyl基への変換, を経て cyclaniliprole（Fig. 1）が 見出された. 上記（1）の構造変換は殺虫スペクトルの拡大 に有効であり，アザミウマなどチョウ目以外の害虫に対し ても本剂は有効である。また，上記（2）の構造変換に関し て, cyclopropyl基をサイズの大きいcyclobutyl基などに変 換すると活性は大きく低下する．本化合物は不斉点を1つ有 


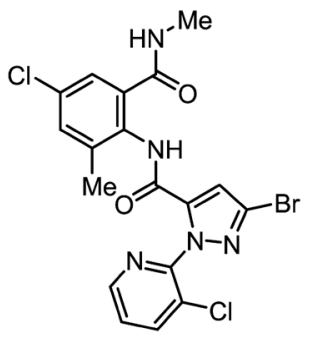

Chlorantraniliprole

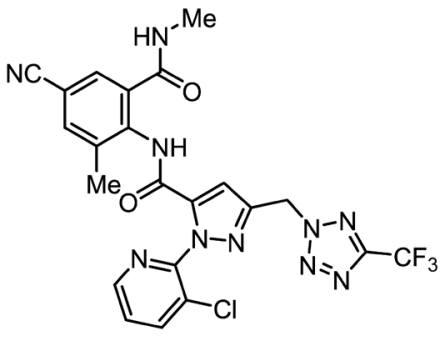

Tetraniliprole

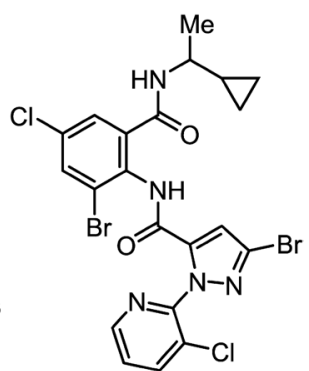

Cyclaniliprole

図3. Diamide系殺虫剤の化学構造.

するが，エナンチオマー間に活性差は認められない。上述 したBayer社の例と比較すると minor 構造展開ではあるも のの, 本剤は作用点変異（G4946E）により抵抗性を獲得し たコナガにも有効とのことであり，本講演も diamide系殺虫 剂の RyR との相互作用について大きな示唆を与えるもので あった。

Biology \& chemistry connected: The development of inscalis ${ }^{\circledR} \quad$ Koradin et al., (BASF, Germany) (3.1.8)

本講演では, BASF, Meiji Seikaファルマ, 北里研究所に より共同開発された新規殺虫剂inscalis（図 4; ISO名：afidopyropen）について紹介があった. 本剤のリードとなった のは, Aspergillus fumigatusやPenicillium coprobiumが産生 する pyripyropene A（PP-A）という天然物である．当初, PP-A はアシル CoA：コレステロールアシル基転移酵素（高 コレステロール血症治療薬の標的分子）の阻害剤として発見 された。その後, ランダムスクリーニングにおいてPP-Aが 吸汁性害虫に対して高い殺虫活性を示すことが判明し，誘 導体合成が行われた結果，さらに性能の向上したinscalisが 見出された。本剂は，（1）P. coprobiumを用いた発酵法に よるPP-Aの生産,（2）加水分解によるアセチル基の除去, （3）アシル化，という3工程を経て製造される. Inscalisは, アブラムシ，コナジラミ，カイガラムシといった半翅目の 吸汁性害虫に高い殺虫効果を示し, 有益昆虫に対する安全 性は高い。本剤の作用点はバニロイド型 transient receptor

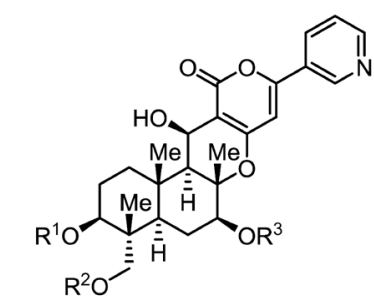

$$
\begin{aligned}
& \text { Pyripyropene A: } R^{1}=R^{2}=R^{3}=A c \\
& \text { Inscalis: } \mathrm{R}^{1}=\mathrm{R}^{2}=-\xi \hat{\mathrm{II}} \longrightarrow \mathrm{C}, \mathrm{R}^{3}=\mathrm{H}
\end{aligned}
$$

図4. Pyripyropene A と inscalis の化学構造.
potential（TRPV）チャネルであり, 弦音器官における感覚 受容を擋乱することで昆虫の摂食行動を妨げる. 本剤の構造 は, 既存の TRPVチャネルモジュレータである pymetrozine や pyrifluquinazon とは大きく異なるものの, 3-pyridyl基を持 つという点については共通している.

Synthesis and biological activity of a novel insecticide, benzpyrimoxan Satoh et al. (Nihon Nohyaku Co., Ltd.) (3.1.10)

P3.14 Benzpyrimoxan, a novel IGR insecticide for control of rice plant hoppers Aoki et al. (Nihon Nohyaku Co., Ltd.)

これら2つの講演では, 新規昆虫生育制御剂（IGR）であ る benzpyrimoxanの発見までの経緯と作用性に関する報告 があったのでまとめて紹介する. Benzpyrimoxanが見出さ れるまでの構造展開は図 5 に表される. ウンカに対して脱 皮阻害作用を示した化合物 1 と 2 の構造を組み合わせた 3 を リードとし，構造展開の結果化合物 $\mathbf{4}$ が見出された。化合物 4 は既存の脱皮阻害剂 buprofezin と同等の殺虫活性を示した が，光安定性が低いために残効性に乏しいという久点があっ た. そこで, リンカー鎖の導入による共役系の分断が試みら れ, オキシメチレンリンカーを持つ化合物 5 を経たのち, 置 換基の最適化が行われて benzpirimoxanが見出された. 本剂

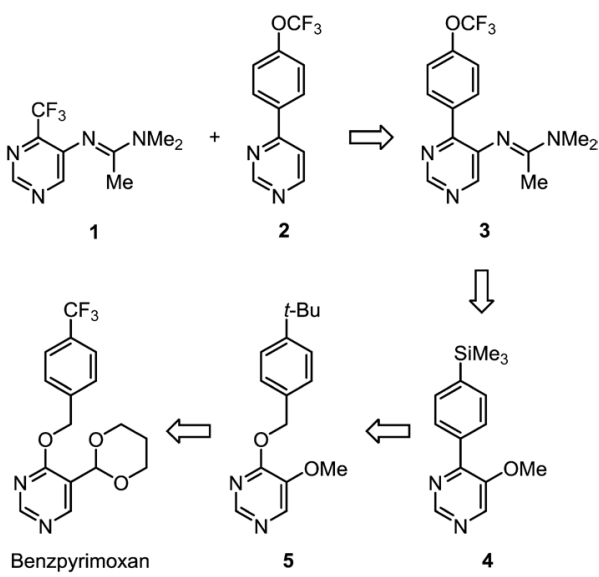

図 5. Benzpyrimoxan に至る構造展開. 
はトビイロウンカをはじめとするウンカ類に特に有効であ り, その他の半翅目昆虫や有益昆虫に対する毒性は低い. 本 剂はbuprofezin とは交差抵抗性を示さず，昆虫に引き起こ す症状は既存のIGR剂とは異なる。これらのことから, 本 剂は新規な作用性を持つ可能性が指摘されており, 今後の作 用機構研究の進展に興味が持たれる.

Cycloclavine: A natural product with insecticidal potential Dickhaut et al. (BASF SE) (3.1.12)

Cycloclavine（図6）は, アフリカ原産のアサガオIpomoea hildebrandtiiや糸状菌Aspergillus japonicusが産生するイ ンドールアルカロイドであり，シクロプロパンを含む $5 つ$ の環が縮合した特徵的な構造を持つ. 本講演では, cycloclavineおよびその類縁体の殺虫活性についての報告があっ た. BASF社において天然化合物ライブラリーのランダムス クリーニングが行われ，アブラムシなどの吸汁性害虫に対 して cycloclavineが殺虫活性を示すことが見出された。こ のスクリーニングにおいて用いられていた cycloclavine は A. japonicusの培養液から単離されたものであったが, さら なる活性評価や誘導体合成を行うためには化合物量が不足し ていた。そこで, A. japonicusの cycloclavine生合成遺伝子 クラスターを酵母に組み込んだ異種発現系が構築され, cycloclavineを大量に供給することに成功した。こうして得た cycloclavine を原料として, 各種置換基が導入された類縁体 が合成されたが，残念ながらいずれの化合物においても殺虫 活性は低下することがわかった．本化合物の作用機構は現状 不明であるが，オクトパミンあるいはセロトニン受容体に作 用する可能性があると演者は言及していた。

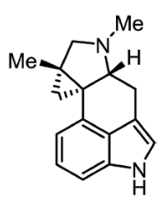

図6. Cycloclavine の化学構造.

Discovery of a novel class of insect ryanodine receptor activators, pyrrole-2-carboxamides Cordova et al. (FMC Agricultural Solutions, USA) (9.3.2)

本講演では, RyRを活性化する新たな化合物クラスであ る pyrrole-2-carboxamide類（図7）の発見までの経緯と作 用性についての紹介があった。演者らは，ショウジョウバエ の RyR Sf-9細胞に発現させたin vitro活性評価系を構築し， 化合物ライブラリーの標的ベーススクリーニング (targetbased screening）を行った。 その結果, pyrrole-2-carboxamide骨格を持つヒット化合物 6 が得られた。構造活性相関 研究の結果選抜された化合物 $\mathbf{7}$ おび 8 は, 演者らの構築し たin vitro活性評価系において上市されている diamide系殺 虫剂と同等の活性を示す。演者らは，(1）これらの化合物 が放射性同位元素でラベルされた diamide系殺虫剂と拮抗 すること，（2）diamide系殺虫剤に抵抗性を与える作用点変 異によりこれらの化合物の活性が低下すること，という2点 から, pyrrole-2-carboxamide類の RyRにおける結合部位は, diamide系殺虫剤のそれと同じであると結論づけた. 残念な がら，化合物 7 およ゙8は殺虫活性を示さない。これは，こ れらの化合物が昆虫体内で速やかに代謝されてしまうことに 起因している.

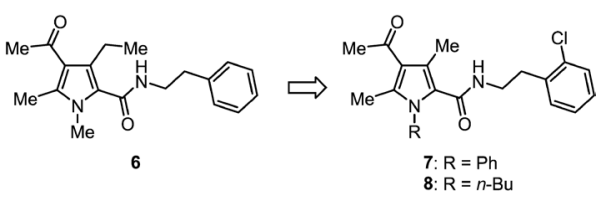

図7. Pyrrole-2-carboxamide類の構造展開.

The mode of action of isocycloseram: A novel isoxazoline insecticide Blythe et al. (Syngenta Crop Protection) (9.3.7)

IsocycloseramはSyngentaにおいて開発されたisoxazoline骨格を有する新規殺虫剂であり, 日産化学が開発した fluralaner や fluxametamideのアナログである（図 8). 本講 演は, isocycloseramの作用機構についてのものであった. Fluralaner やfluxametamide と同じく, 本剂は $\gamma$-アミノ酪 酸作動性塩素イオンチャネル（GABACl）を低濃度で阻害 し, 抑制性神経伝達を遮断することで殺虫効果を示す。演者 らは, ショウジョウバエの $\mathrm{GABACl}$ 変異体を用いた電気生 理学実験を行い, isocycloseramの結合サイトについて検討 した. Fipronilに抵抗性を与える変異 GABACl（A301S）に 対し, isocycloseramは高い阻害活性を保持していたことか ら，本剂はfipronil とは異なる部位に結合することが示唆さ れた. 一方で, meta-diamide類（Fig. 6）に抵抗性を与える 変異 GABACl（G335M）に対しては, isocycloseramの阻害 活性は大幅に低下していたことから, 本剂はmeta-diamide 類と同じ部位に結合することが示唆された。これらの結果 は, isocycloseramのトリチウム標識体（[ $\left.{ }^{3} \mathrm{H}\right]$ isocycloseram） を用いた結合試験によっても確認された。すなわち，fipronil $\left[{ }^{3} \mathrm{H}\right]$ isocycloseram と拮抗せず, meta-diamide類は拮 抗した。また, グルタミン酸作動性塩素イオンチャネル （GluCl）に作用する mectin類も, 10,000倍ほど低い親和性で はあるが， $\left[{ }^{3} \mathrm{H}\right]$ isocycloseram と拮抗して GABAClに結合す るとのことである. 本研究の成果は, site-directed mutagenesis を用いて GABACl と GluClによるリガンド認識を解析し た尾添嘉久先生（島根大学）らの発表（講演番号9.3.1）と 整合性の取れるものであった。 


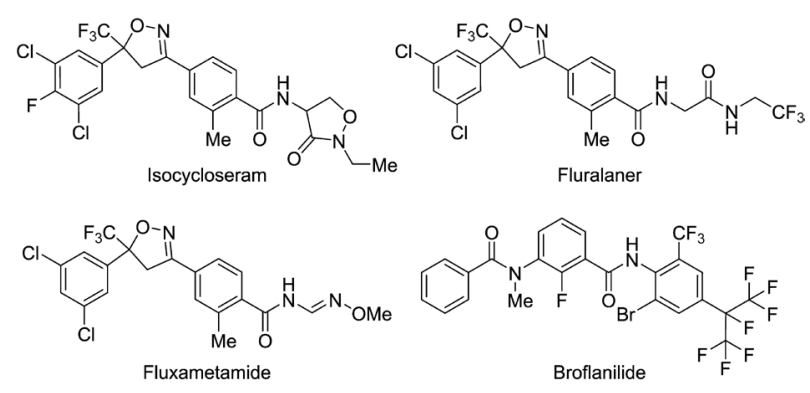

図 8. Isoxazoline類（isocycloseram, fluralaner, fluxametamide）と meta-diamide類（broflanilide）の化学構造.

Cuticle alterations and $\mathbf{P 4 5 0}$ detoxification are associated with deltamethrin and/or DDT resistance in Anopheles arabiensis populations from Ethiopia Simma et al. (Jimma University) (9.3.11)

エチオピアに生息するハマダラカの一種 Anopheles arabiensisの個体群は，電位依存性ナトリウムチャネルに作用す る deltamethrinおよびDDTに詨して強い抵抗性を示す。こ れらの個体群においては作用点変異（L1014F）が高い頻度 で見出されているものの, それだけではこの抵抗性の強さを 説明できない，そこで演者らは，RNA-seqによるトランス クリプトーム解析を行い, 抵抗性および感受性個体群の間で 遺伝子発現の差異を比較した。 その結果, 抵抗性個体群で はグルタチオン-S-トランスフェラーゼをコードする gstd 3 お よびシトクロムP450をコードするcyp6p4が過剩発現されて おり，薬物代謝が活性化されていることが示された。さら に, 表皮外層（エピクチクラ）に含まれる炭化水素の生合成 に関わるcyp4g16の発現量も有意に上昇していた。このこと から, 抵抗性A. arabiensisではエピクチクラの炭化水素量が 増すことで，疎水性の高い薬剤の吸収が妨げられているこ とが示唆された。このように，A. arabiensisの deltamethrin/ DDT抵抗性は複合的な要因で引き起こされているという興 味深い報告であった。

(横井大洋)

\section{6. 除草剂}

Aclonifen-Deciphering a novel mode of action of a commercialized herbicide using systems biology Kahlau et al. (Bayer AG) (9.2.1) プログラムではvon Koskull

本講演では，ジフェニルエーテル系除草剤であるアクロニ フェン（ACL）（図9）の作用機構をシステムバイオロジー研 究によって解明した成果が発表された。一般的にジフェニ ルエーテル系の作用機構は，プロトポルフィリンオキシダー ゼ（PPO）の阻害であり，その効果は白化作用として表れ る. ACLを処理した植物において白化やプロトポルフィリ ンIXの蓄積が確認されるものの, PPOの阻害活性は確認で きず，その作用機構はこれまで不明であった．演者らは一連 のオミクス解析により, その作用点が葉緑体のソラネシル二 リン酸合成酵素（SPS）であることを明らかにした。これは
除草剤の作用点として新規である。この酵素はプラストキ ノン（PQ）の生合成に関わっており，この合成が阻害され ることで, $\mathrm{PQ}$ を補酵素として必要とするカロテノイド合成 が停止し，白化作用として表れることが示された。さらに， ACL と SPSの共結晶構造解析により，ACLが基質であるイ ソプレノイドが通るSPSダイマー間のチャネルに結合するこ とが明らかとなり, 作物との選択性はアミノ酸レベルで決定 づけられることも示された. 今後SPSを標的とする除草剤の 開発展開が期待される.

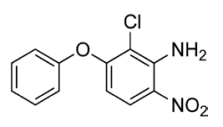

図9. Aclonifen の化学構造.

Disruption of plant de novo pyrimidine biosynthesis at a specific step in the pathway by a new class of herbicide causes selective phytotoxicity with commercial levels of activity Kang et al. (FMC Agricultural Solutions) (9.2.2)

The discovery of aryl pyrrolidinone anilides: A new modeof-action herbicide class that inhibits dihydroorotate dehydrogenase Selby et al. (FMC Agricultural Solutions) (3.4.1)

9.2.1に引き続き除草剂の新規作用機構に関する発表が 行われた. 演者らはアリルピロリジノンアニリド化合物 （図 10）に抵抗性を示すシロイヌナズナ系統のSNPマッピン グによって, 抵抗性アリルが5番染色体上にあることを明ら かにした，戻し交配により，原因遺伝子を12遺伝子に絞り 込んだ.さらに, メタボロミクスによって, これらの化合物 の作用点がピリミジン生合成経路に存在すると予想し, 最終 的にこれらの化合物の作用機構がミトコンドリア内膜に局在 するジヒドロオロト酸デヒドロゲナーゼ（DHOD）である ことを明らかにした。実際に，これらの化合物による成長抑 制効果は反応産物であるオロト酸によって緩和されること も確認された. ITC, SPR, およびフラグメント結合アッセ イなどにより,これらの化合物が DHODの補酵素（電子受 
容体）であるユビキノン結合部位に作用することも明らかに なった．ただし，この作用機構で選択性は説明できず，さら なる解析が必要とのことであった.

3.4.1でも関連の発表があり，こちらではこれらの化合物 のSARによる構造最適化, 立体選択的合成法の確立につい て報告された。また，選択性についてジャポニカ米に安全で あること，これまでに選択性の原因遺伝子に関連すると考え られる41 SNPsが発見されていることが紹介された。

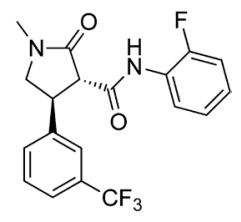

図 10.アリルピロリジノン化合物 tetflupyrolimet の化学構造.

\section{Unraveling herbicide detoxification mechanisms in several plant species. Implication for non-target site weed resis- tance management. Beffa (Bayer AG) (9.2.5)}

本講演では，除草剂の代謝酵素の誘導による抵抗性メカ ニズムについてRNA-Seqを用いたトランスクリプトーム解 析を行った事例が紹介された。 まず，フルフェナセット抵 抗性について解析したところ, 抵抗性系統で95のコンティ グの発現誘導が確認され, そのうち 11 がグルタチオン $S$-転 移酵素（GST）であった。このうちの9遺伝子はGST tau ラスに属しており, 残りの2遺伝子は別のクラスに属してい た。組換え蛋白質を用いた酵素アッセイによってGST1Aが フルフェナセットを基質とすることが確認され，抵抗性は GST1Aによるフルフェナセットのグルタチオン抱合が主要 因であることが明らかになった。一方, ALS阻害剤の抵抗性 はCYP81A1の発現による代謝が関与しており，この酵素を イネカルスで発現させるとジクロホップメチルやクロロスル フロンに対する抵抗性が付与されることが示された。ALS阻 害剂抵抗性系統のトランスクリプトームによって他の CYPs が過剩発現していることも明らかになった.4-HPPD阻害剂 であるテンボトリオン抵抗性についても, トランスクリプ トーム解析により2種のCYPの過剩発現が確認された。今 後, HRACとCYPおよびGST感受性の関係について興味が 持たれるとのことであった.

Crop specificity of herbicide safeners Giannakopoulos et al. (Newcastle University) (9.2.6)

クリプロスルファミド（CSA）（図11）は, 除草剂の薬害 を低減するセーフナーとしての活性を有するが, トウモロコ シでその効果が確認されるものの, コムギでは効果が確認で きない. 本講演では, CSAの作用機構や植物種間での活性
差の原因についての解析結果が紹介された。 まず，CSAの 植物体内での移動が，コムギで早くトウモロコシでは遅い ということが明らかになった.さらに，トウモロコシでは CSAが水酸化および脱メチル化を受けやすいということも 明らかになり, これらの現象が植物種間での活性差の要因で あることが示唆された。 また, CSAは除草剤の代謝を強め ることで, 薬害を低減している可能性が示された。さらに, ALS阻害剂であるチエンカルバゾンメチル（TCM）とCSA が植物内で共局在していることが, MALDIイメージングに よって示された.この観察結果と CSAの活性の関係につい てはさらなる解析が必要と考えられるが, 非常に興味深い現 象であり，今後の展開に期待がもたれる。

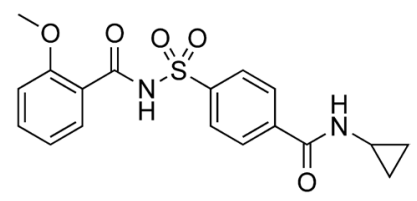

図11. クリプロスルファミドの化学構造.

Reactive oxygen species trigger the fast action of glufosinate Dayan et al. (Colorado State University) (9.2.7)

グルタミン合成酵素（GS）は植物の窒素代謝で中心的な 役割を果たしており，その阻害は植物を直ちに死に至らしめ る.しかし，このような迅速な殺草活性を誘導する生化学， 生理学的メカニズムはいまだ明らかでないとして, 演者ら は活性酸素種（ROS）に着目した，まず，グルホシネートを 植物体の茥頂および基部に投与し, その移動を調べたところ 上部への移動のみが確認されたことから, グルホシネートは アポプラスト経由で道管を移動していることが明らかとなっ た. $\mathrm{C}_{3}$ 植物と $\mathrm{C}_{4}$ 植物では, グルホシネートの吸収量が異な り,これはグルホシネート感受性と相関していた. また，こ の量は従来から毒性の原因と考えられているアンモニアの蓄 積量とも相関していた. しかし，in vitroの実験では，アン モニアの量と炭素固定量の低下や細胞死との相関がないこと が明らかになった. 一方, グルホシネートの投与により, 光 照射下でROSが大量に発生し, 細胞膜脂質の過酸化が誘導 されることが明らかになり，これが迅速な細胞死の原因であ ることが示唆された. グルホシネートの効果は, 成熟葉で顕 著であり, 幼若葉には表れない. GS はどちらの葉でも阻害 されており, アンモニアも蓄積していることが確認された。 一方, ROSの発生量が成熟葉で多く, in vitroで観察された 現象と一致する結果となった。したがってグルホシネートの 迅速な殺草活性はROSの発生が原因である可能性が示され た. 


\section{Luximo $^{\mathrm{TM}}$ herbicide-Rediscovering a dormant molecule} Kraus (BASF SE) (3.4.2) プログラムではWitschel

1980/90年代にイネ用の除草骫として開発された cinmethylin（図 12）は合成費用が高く一旦お蔵入りとなったもの の, イネ科に対する高い選択性から再評価した結果, 新規 作用機構を有する Luximo ${ }^{\mathrm{TM}}$ として実用化にいたった内容に ついて発表された．アオウキクサ（Lemna paucicostata）の 蛋白質抽出液を用いて, cinmethylinに結合する蛋白質を探 索したところ, 脂肪酸合成の最終段階である脂肪酸とアシ ルキャリア蛋白質の加水分解を触媒するチオエステラーゼ （FAT）であることが明らかになった. Cinmethylinを投与 した植物では, 飽和脂肪酸の減少が確認され, その作用機構 が明らかとなったＦATとの共結晶解析により，化合物の 結合部位も明らかにされた。イネ科に対する高い選択性は, ADMEの違いによるものとの説明がなされた。

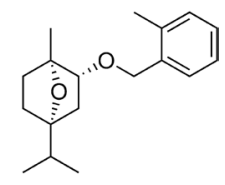

図 12. Cinmethylin の化学構造.

Discovery and mode of action of cyclopyrimorate, a new paddy rice herbicide Shino et al. (Mitsui Chemicals Agro, Inc.) (3.4.3)

三井化学アグロによって開発された新規作用機構をもつ シクロピリモレート（図13）について発表がなされた。こ の化合物は4-HPPD阻害剂と相乗的な効果を発揮し，水田 雑草に白化作用を示す．シクロピリモレートを処理した植 物中で, ホモゲンチジン酸量が上昇し, プラストキノンが減 少していたことから, その作用点がプラストキノン生合成 経路中のホモゲンチジン酸ソラネシルトランスフェラーゼ （HST）であると予想された。 また，植物中から代謝物であ るデスモルフォリノカルボニルシクロピリモレート（DMC） （図 13）が検出された.In vitroでの阻害試験により, 親化合 物の HST に対する $\mathrm{IC}_{50}$ が561 $\mu \mathrm{M}$ であったのに対し, DMC の $\mathrm{IC}_{50}$ は $3.9 \mu \mathrm{M}$ と強い阻害活性を有することが明らかに なった。この活性と白化作用には相関が見られ，シクロピリ モレートの作用機構が代謝物DMCによるHST阻害である ことが明らかになった。選択性については未だ不明であり，

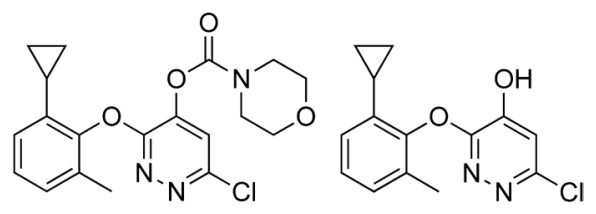

図13. シクロピリモレート（左）およびデスモルフォリノカル ボニルシクロピリモレート（DMC）（右）の化学構造.
今後の研究の進展が期待される.なお, シクロピリモレート については, J. Pestic. Sci., 43, 233-239（2018）も参照された い.

A new herbicide mode of action from a bioherbicide component, spliceostatin C Duke et al. (USDA, Marrone Bio Innovations) (3.4.4)

微生物由来のバイオ除草剂MBI-014の成分の一つであ る spliceostatin C（図 14）の作用機構に関して発表された. MBI-014 は土壌微生物 Burkholderia rinojensis 由来のアマラ ンサスなどの雑草に低容量で効果を発揮するバイオ除草剤で ある。植物に毒性を示す成分として spliceostatin Cが同定さ れており, 関連化合物の spliceostatin A（図 15）はスプライ セオソームを阻害し, mRNAのスプライシングに異常をも たらすことが知られている. Spliceostatin Cはシロイヌナズ ナの白化や成長阻害をもたらす。この化合物を処理したシロ イヌナズナの遺伝子発現解析を行ったところ, 転写物のス プライシングが影響を受けていることが明らかになり, やは り spliceostatin Cがスプライセオソーム阻害を介した殺草活 性を有していることが示された。講演では, 他の成分である romidepsinがヒストン脱アセチル化酵素の阻害活性を有し ていることも紹介された.これらの成分が遺伝子の発現や翻 訳に大きな影響を与えると予想されることからその安全性が 気になるところである，実際に会場から安全性に関する質問 が出されたところ, 明確な回答はなされなかったことを付記 する。

(岡澤敦司)

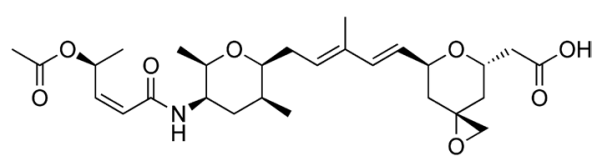

図 14. Spliceostatin Cの化学構造.

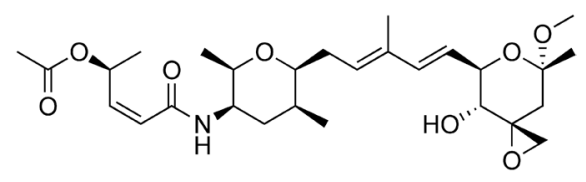

図 15. Spluceistatin Aの化学構造.

\section{7. 殺菌剂}

Aminopyrifen, a novel 2-amino nicotinate fungicide with a unique mode of action and broad-spectrum Hatamoto et al. (Agro-Kanesho Co., Japan) (9.1.1)

本講演では, アグロカネショウ社が開発した殺菌剂アミノ ピリフェン（図16）の開発経緯等と作用機構についての研 究紹介がなされた。本剂は, 灰色かび病菌Botrytis cinereaや Fusarium oxysporum どの植物病原糸状菌に対して強い殺 
菌作用を示す．特に，他の真菌剤と交差抵抗性を示さないこ とから，その作用機構に興味が持たれた. Neurospora crassa を使った解析から, 胞子の発芽菅の形態変化 (発芽菅の伸長 抑制）が本剂に特徵的であったため, 新規の作用機構が考え られ，変異株などを用いた詳細な解析から，ターゲットタン パク質の候補としてGWT1が同定された。つまり，アミノ ピリフェンは真菌の細胞壁の整合性に関わる部分を阻害する 可能性が高いと結論付けた。ユニークな作用機構，広い殺菌 スペクトラムおよび高いフィールドでの効果を持つ殺菌剤と して, 大変興味深い講演であった.

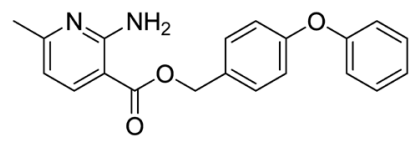

図 16. Aminopyrifen の構造.

Different sensitivity of sclerotinia sclerotiorum towards SDHIs with both target site and non-target site mutations identified through sensitivity monitoring in Japan and France Yamashita et al. (Nihon Noyaku Co., Japan) (9.1.2) 本講演では, フランスと日本を調査対象とし, 日本農薬 で開発されたpyraziflumid（図 17）を含むSDHI剂に対する 菌核菌 Sclerotiia sclerotiorum（Sc）の感受性株と低感受性株 についての詳細な研究報告がなされた。今回見出した菌株 群は，低感受性株としてこれまでに得られたもので見られ た succinate dehydrogenaseのアミノ酸変異体ではなかった. 今回の低感受性株の succinate dehydrogenaseは, そもそも が pyrazole-carboxylic acid型のSDHI剂が効き難い酵素で あった。一方で，そのような部分構造をもたない fluopyram や pyraziflumidには感受性を示した．最終的に，少なくとも 日本では, SHI剂が一般的になる前から遺伝学的な多様性と して pyrazole-carboxylic acid型のSDHI剤に対して低感受性 の菌株が存在していたと結論づけていた。とても面白い内容 であったため, 質疑応答が活発であった.

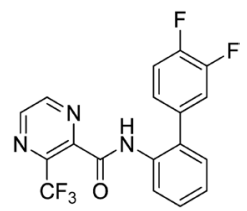

図 17. Pyraziflumid の構造.

The mitochondrial complex III inhibitor Ametoctradin has an unusual binding mode Fehr and Zito, (BASF SE, Germany) (9.1.3)

本講演では, BASF社が開発した殺菌剂Ametoctradin （図 18）の開発経緯等と作用機構についての研究紹介がなさ
れた。本剂は，卵菌類の cytochrome $b c_{1}$ 複合体に作用する ことはわかっていたが, 今回新たに, in vitroの詳細な生化 学的解析を進めていた. cytochrome $b c_{1}$ 複合体の $\mathrm{Q}_{\mathrm{o}}$-と $\mathrm{Q}_{\mathrm{i}}$ サイトの両方に結合可能なため, $\mathrm{Q}_{\mathrm{i}}{ }^{-}$サイト結合の既存剤 CyazofamidやAmisulbrom とは異なった効果を示すことが 予想された。 ただ，その詳細を理解しきれなかった，卵菌と モデル生物である酵母を，上手く使い合わせて結論を導き出 していた.

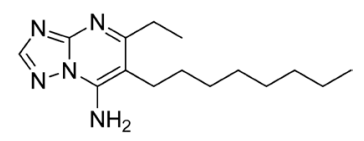

図 18. Ametoctradin の構造.

Isotianil-A new tool for the control of wheat blast caused by Magnaporte oryzae Triticum/Pyricularia gramminitritici, an emarging glabal threat Portz (Bayer, Germany) (9.1.5)

本講演では, Bayer社の Portzから殺菌剂 Isotianil（図 19） の開発経緯等と作用機構についての研究紹介がなされた. 稲 作の大敵であるいもち病の防除剂として, Bayer社と住友 化学が共同開発したのが本剂である. 本剂は, いもち病菌 Magnaporthe griseaに殺菌作用を示さず, 植物病害抵抗反応 を誘導するのが特徴である.今回は，イネではなくコムギい もち病への有効性（低薬量, 長期間の効果持続）が報告さ れ，基本的には同じように植物病害抵抗性を誘導していると のことだった，有名な薬剂だが，まだまだ有効な事例がある ように感じた。

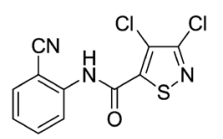

図 19. Isotianilの構造.

Discovery of ADEPIDYN ${ }^{\mathrm{TM}}$ Stierli, Haas, Rajan, Walter, Lambert, Cederbaum (Syngenta Crop Protection AG, Switzerland) (3.2.1)

本講演では, Syngenta社が開発した殺菌剤ADEPIDYN (pydiflumetofen, 図20）の開発経緯についての研究紹介が なされた。本剤は，コハク酸脱水素酵素阻害剂（SDHI）に 属する殺菌剤であり, その作用機構は真菌のミトコンドリア

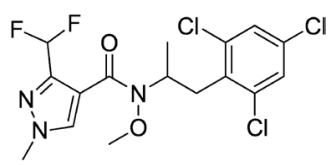

図 20. ADEPIDYN の構造. 
電子伝達系複合体 II に作用することにより，呼吸阻害を引き 起こすというものである，開発経緯は，農薬開発で一般的な 手法で, 有効な基本構造を出発点として構造展開していった ようであった．植物体内での動態が他剤よりも優れている， 特に植物体内での移行性の話をされていた。また，胞子の発 芽阻害と発芽菅伸長のいずれに対しても他剂よりも優れた効 果を示すことが報告された。

\section{Isofetamid: Discovery and optimization of a novel fungi-}

cide Yoneda et al. (Ishihara Sangyo Kaisha Ltd.) (3.2.5)

本講演では, 石原産業が開発した殺菌剂isofetamid （図21）の開発経緯についての研究紹介がなされた。本剤 は, 殺菌剤の有効なターゲットであるミトコンドリア電子伝 達系複合体 II のコハク酸脱水素酵素を阻害する。いわ他る SDHI剂である。既存剤に対する抵抗性出現の問題から，新 剤開発が切望されており，農薬メーカーが集中的に力を入れ ていることは言うまでもない，殺線虫剂研究の流れからきた 化合物群に殺菌活性が見つかったことに端を発したようであ る. 薬剤の基本構造が aminoisobutyric acidの両側にベンゼ ン環とチオフェンが付いたものなので，合成的な構造展開が 容易だったようで多数の構造アナログが合成され，活性評 価されていた．SDHに対する結合様式の予測もされており， 抵抗性変異酵素に対して，有効に結合するモデルが提唱され ていた，残効性，耐雨性および浸透性も優れる．SDHI剂の 特徵である広い殺菌スペクトラムも有していた。

（甲斐建次）

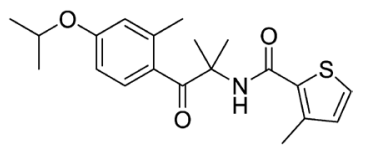

図21. Isofetamid の構造.

\section{8. 環境・製剤など}

オーストラリア・Monash Universityの Borrowman によ るスプレー型高分子マルチ剂の開発，その雑草抑制などの マルチ効果と土壌微生物による分解までを紹介した”Mulching efficacy and effect on soil microbial health of a sprayable, biodegradable polymeric mulch”が印象的であった。低融点 ポリエチレンを用いたマルチシートは，保湿，雑草防除，土 袞飛散抑制，土袞伝播性微生物と露地物作物との接触抑制， 地面温度の安定化等, 複合的な効果を示し，これを用いると 水利用効率で最大 $50 \%$ ，作物によっては収穫性が 20-70\%向 上する。しかしながら，使用済みのマルチシートはそのほと んどが土袞に鋤き込まれ，近年の廃プラスチックやミクロプ ラスチックによる海洋污染に匹敵する深刻な土袞污染が指 摘されており，土㙋の健全性と作物収穫量への影響が懸念 されている. Borrowmanは, Adhikariらが開発した土㙥㽞
表面にスプレーできる水溶性生分解性高分子を従来の低融 点ポリエチレンシート製マルチと比較し，トマトを使ってそ の実行性を検討した。結果, 土壌表面で固まった水溶性生分 解性高分子は従来のマルチング資材に匹敵するマルチ効果を 示した。この新規ポリマーは, 高分子業界ではソフトセグ メントと呼ばれる末端ヒドロキシ化中鎖アルキルカルボン 酸ユニットがエステル結合し，時折，へテロモノマーが取り 込まれている高分子で，このエステル結合を幾つかの土壌微 生物が分解し, 最終的には無機化する. 個人的には, この分 解中途の化合物が連作障害を引き起こすフザリウムなどに 対する選択的な殺菌性を示せばより面白いだろうと考えた。 この biodegradable polymeric mulchはCSIRO との共同研究 "Degradation of a sprayable, biodegradable polymeric mulch in different soil types”として，土㙵タイプによる易分解性， 難分解性を評価するなど，実用化の部分を強調したポスター 発表も並行してなされていた。

そのほか，興味を引く口頭発表として，オランダの Jacob van den Borneによる plenary talk: Precision Agriculture in Practice「スマート農業の実践」(22, May) を挙げておきた い，実際に営農に携わっているvan den Borneによる講演 は，スマート農業に取り組む農業経営者が，いかにビッグ データを駆使し，最短距離での耕起ルートの算定によるトラ ク夕燃料節減や圃場履歴による病虫害発生忌避, 散水や施 肥, 農薬散布に代表される農地管理の低コスト化, ならびに 生産物価格維持の価格予想に取り組み, 大きな成果を挙げて いる例を語った，特に農薬は, 病気が発生した地点とその周 辺へのドローンによるピンポイント薬剤散布によって，その 使用量を大幅に削減することができたと報告している，近未 来のスマート農業では, 予防的な戋場全体への薬剤散布では なく, 病気の発生や虫害の広がりをいち早くセンシングし, その部分をケアする「治療的」ピンポイント薬剤散布が普及 しているかもしれない.

私の担当分野ではないが，天然物関係の発表を少し紹介す ることにする. 今大会は天然物を利用した病虫害防除の実践 に関する研究報告例が，ヨーロッパの研究グループを中心に 飛躍的に増加したように感じられた。しかし，それらのほと んどがセージやタイム，ローズマリーなど，ヨーロッパの伝 統的ハーブ・エッセンシャルオイルをランダムスクリーニン グ的に用いており, 現象に基づいた活性物質探索ではなかっ た。また，活性があったとの報告事例でも，既存農薬に比べ てそれらの活性は著しく弱く, 低い防除効果しか得られて いなかった，それでも減農薬が「食の安全」を最優先とする $\mathrm{EU}$ の農業政策が, 天然物による病虫害防除やその限界を超 える画期的成果を生むか，一作物の壊滅に繋がる破綻を引き 起こすか，注視して行きたい，

筆者は 22 日からへントに入ったが，滞在 1 日目に思わぬ 異常低温と遭遇し，風邪を引いてしまった．ガラガラ声なが 
らも，Burkholderia plantariiが産生するファイトトキシンで あるトロポロン産生がSphingobium yanoikuyae EC-S001株 のクオルモンシグナル，N-3-hydroxyoctanoyl-L-homoserine lactone とそのジアステレオマー等量混合物の終濃度 $0.4 \mathrm{nM}$ 添加で最大 7 倍量増えることに加え，そのまま殺菌後に培 養液を除草剂に使えるかもしれないとの内容についでNew approach to a bacterial causative crop disease and weed con- trols, using N-3-hydroxyoctanoyl-L-homoserine lactone, a tropolone biosynthetic activator for Burkholderia plantarii" $と$ いうタイトルで発表した. 残念ながら発表直後には大きな反 響はなかったが，一つの方向性は示すことが出来たと前向き に捉えている.

（橋床泰之） 